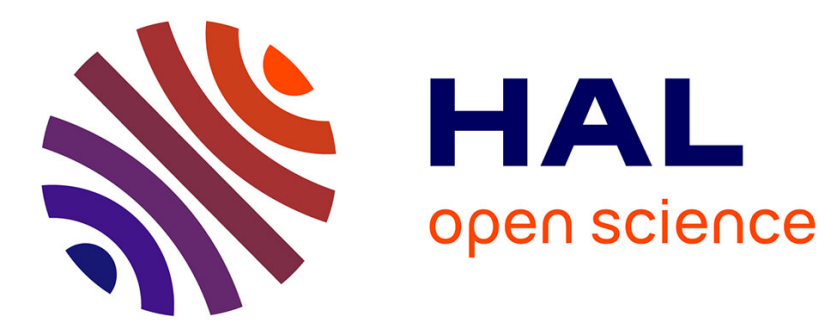

\title{
Insecurity and Welfare: evidence from country data
}

Marcel Fafchamps, Bart Minten

\section{To cite this version:}

Marcel Fafchamps, Bart Minten. Insecurity and Welfare: evidence from country data. The Journal of Development Studies, 2009, 45 (06), pp.831-863. 10.1080/00220380902802206 • hal-00518322

\section{HAL Id: hal-00518322 \\ https://hal.science/hal-00518322}

Submitted on 17 Sep 2010

HAL is a multi-disciplinary open access archive for the deposit and dissemination of scientific research documents, whether they are published or not. The documents may come from teaching and research institutions in France or abroad, or from public or private research centers.
L'archive ouverte pluridisciplinaire HAL, est destinée au dépôt et à la diffusion de documents scientifiques de niveau recherche, publiés ou non, émanant des établissements d'enseignement et de recherche français ou étrangers, des laboratoires publics ou privés. 


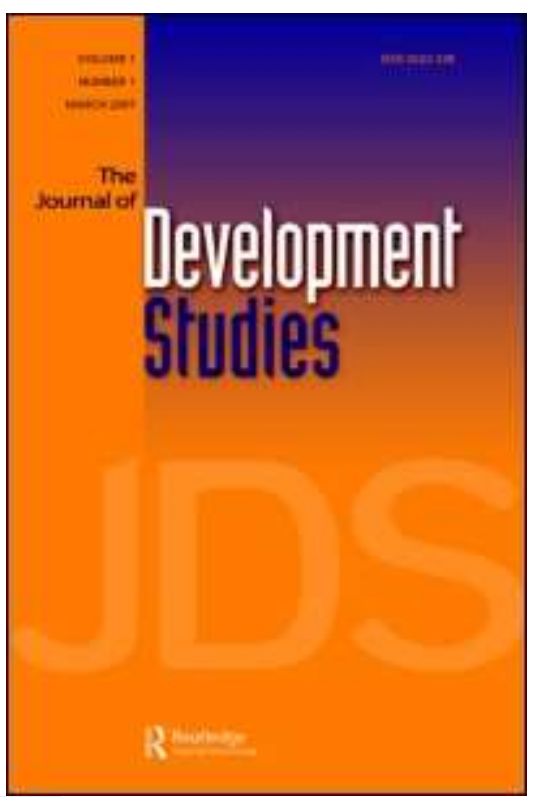

Insecurity and Welfare: evidence from country data

\begin{tabular}{|r|l|}
\hline Journal: & Journal of Development Studies \\
\hline Manuscript ID: & FJDS-2007-Aug-0026.R2 \\
\hline Manuscript Type: & Original Manuscripts \\
\hline Keywords: & crime, school enrollment, health, project placement \\
\hline \multicolumn{2}{|l}{} \\
\hline
\end{tabular}

\section{s scholarONE" \\ Manuscript Central}


Poliara

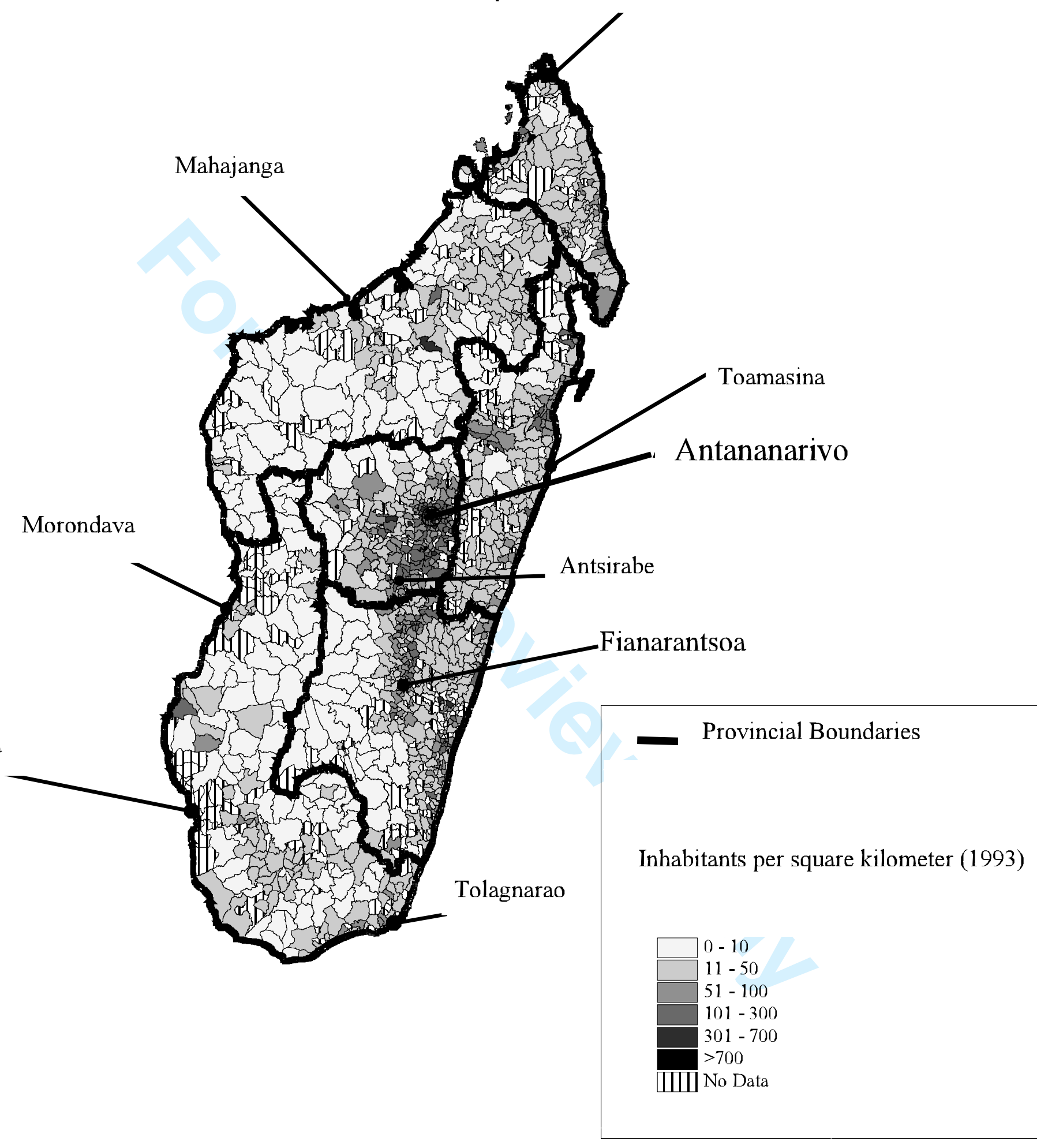

Figure 1. Population densityand maijor.ccities of Madagascar 
Insecurity and Welfare:

Evidence from County Data ${ }^{\mathrm{i}}$

\author{
Marcel Fafchamps, Oxford University, UK ${ }^{\mathrm{ii}}$ \\ Bart Minten, IFPRI, India ${ }^{\text {iii }}$
}

\begin{abstract}
Using original survey data collected at the county (commune) level, we examine the relationship between insecurity and welfare. Correcting for unobserved heterogeneity at the commune level, we find that insecurity is associated with lower incomes and health status in all our analysis, and it is associated with lower school enrollment and higher infant mortality in some regressions. Results are robust to the inclusion of shocks potentially affecting both welfare and insecurity. We further find a significant association between insecurity and the provision of certain public services, notably schooling and health care. A similar relationship is found with the placement of development projects. Taken together, the evidence suggests that insecurity is an important determinant of welfare in the country studied.
\end{abstract}

Keywords: crime, school enrollment, health, project placement

JEL: O15, I38, K42

URL: http://mc.manuscriptcentral.com/fjds 


\section{Introduction}

It is increasingly recognized that human welfare is affected by the insecurity brought up by war, civil strife, and crime (e.g. Clinard and Abbott, 1973; Bourguignon, 2000). Direct effects arise from victimization and the fear it instills in neighbors, relatives, and members of the community at large. Indirect effects come from reduced investment and incomes and from diminished provision of -and access to -- public services.

This paper examines the indirect effect of crime-driven insecurity on incomes and public services. We test whether insecurity is associated with a reduction in various welfare indicators. Attempts to investigate this relationship are typically hindered by the need to control for unobserved heterogeneity. We overcome this difficulty by using what amounts to location-specific fixed effects. Other empirical investigations of insecurity and welfare have relied primarily on crosscountry comparisons (e.g. Soares, 2004; Fajnzylber, Lederman and Loayza, 2002a, 2002b; Gaviria and Pages, 2001), with all the difficulties inherent to this kind of research -- e.g., different data sources, time period, cultures, etc. Here we use data coming from a single country that were collected at the same time using the same questionnaire. The data covers the whole country.

Results show that an increase in insecurity is associated with a significant reduction in incomes and in access to health centers and schools. The effect is robust to the inclusion of various controls, and the use of alternative methods such as propensity score matching or instrumental variable regression. We also investigate possible channels through which insecurity may affect welfare. We find that a rise in insecurity in a given location is associated with a reduction in the likelihood that a new school or health center is built there. We also provide evidence that insecurity is associated with a reduction in the likelihood of attracting a development project. Results further indicate that certain types of economic activity such as large-scale manufacturing are more sensitive to changes in insecurity than others, like small-scale mining.

These findings are by themselves not surprising. What is surprising is that they are so strong in a country that is not known for drug trade or guerilla activity. In spite of attracting many tourists and sizeable foreign investment, the studied country suffers from what could be called pervasive low- 
level insecurity. Much of it is related to property crime and the ineffectiveness of the police and prison system (e.g. Ministère de la Justice, 1999; Fafchamps and Moser, 2003). This study shows that crime and the feelings of insecurity it generates seem to have large welfare effects through economic activity and the provision of public services.

Since Becker's (1968) initial foray, an economic literature on crime has emerged and is now well established in developed countries. Much of this work has focused on the issues of deterrence (e.g. Ehrlich and Brower, 1987; Ehrlich, 1996; Levitt, 1996, 1997, 1998; Farmer and Terrell, 2001) and the determinants of criminal behavior (e.g. Ehrlich, 1975; Blau and Blau, 1982; Sah, 1991; Ludwig, Duncan and Hirschfield, 2001; Morgan, 2000; Freeman, 1996; Raphael and Winter-Ember, 2001; DiIulio, 1996). Some work has also been done on the cost of crime prevention to individuals and on the effect that crime has on investment and the choice of residence (e.g. Cullen and Levitt, 1999; Freeman, Grogger and Sonstelie, 1996; Helsley and Strange, 1999).

More recently, the literature has turned to the study of crime in poor and middle-income countries. In a series of articles relying on cross-country comparisons, Fajnzylber, Lederman and Loayza show that crime-related insecurity hurts growth (e.g. Fajnzylber, Lederman and Loayza, 1998, 2000, 2002a, 2002b; Lederman, Loayza and Menendez, 2000). There is also a growing body of work based on micro data. Pradhan and Ravallion (1999), for instance, show that insecurity ranks high on the welfare priorities of Tanzanian dwellers. Demombynes and Ozler (2002) examine crime in South Africa and show that high crime rates in poor districts spill over to richer neighborhoods. Using data from Madagascar, Fafchamps and Moser (2003) show that the incidence of certain categories of crime is higher in isolated areas than in urban centers, thereby reversing the general perception that crime is primarily an urban phenomenon. The authors also show that police deterrence is ineffective in Madagascar. Fafchamps and Minten (2006) further show that an exogenous increase in poverty is associated with a rise in crop theft.

This literature has recently been joined by economic work on conflicts. Collier and Hoeffler (1998) and Collier and Hoeffler (2002) have shown that many violent political conflicts follow an economic rationale, particularly the capture of a valuable income source such as a diamond mine. Using cross-country evidence, Collier, Hoeffler and Soderbom (2004) show that once initiated, 
violent political conflict tends to persist. The relationship between crime and conflicts is examined by Collier and Hoeffler (2004) who provide evidence that conflicts fuel crime but not the reverse. Using panel household data from Uganda which has been plagued by civil war for a decade or more, Deininger (2003) shows that civil strife reduces welfare, but crime does not. In contrast to the existing literature, this paper empirically tests the association between welfare and insecurity and investigates the channels through which these effects are likely to take place.

The paper is organized as follows. In Section 2, we briefly present the conceptual framework and testing strategy. Section 3 discusses the data and presents summary statistics. In Section 4 we test whether insecurity reduces welfare. Section 5 examines a number of channels through which insecurity affects welfare. Conclusions and suggestions for further research are presented at the end.

\section{Conceptual Framework}

Following Becker (1968), it is now customary to recognize that crime responds to economic incentives. Crime is also widely believed to affect economic incentives, although the magnitude of this effect is unclear. Other sources of insecurity, such as riots, civil wars and political conflict, are similarly thought to influence economic outcomes.

To investigate the relationship between insecurity and welfare, we estimate regressions of the form:

$$
\mathrm{W}_{\mathrm{it}}=\alpha \mathrm{S}_{\mathrm{it}}+\beta \mathrm{C}_{\mathrm{it}}+\mu_{\mathrm{i}}+\varepsilon_{\mathrm{it}}
$$

where $\mathrm{W}_{\mathrm{it}}$ is a welfare indicator for location $i$ at time $t, \mathrm{~S}_{\mathrm{it}}$ is a measure of insecurity, $\mathrm{C}_{\mathrm{it} \mathrm{i}} \mathrm{S}$ a vector of controls, $\mu_{\mathrm{i}}$ is a fixed effect, and $\varepsilon_{\mathrm{it}}$ is an error term. The fixed effect captures any locationspecific time-invariant factor that may affect welfare. Controlling for such effects is essential because many location-specific features such as isolation or population density may influence welfare as well as insecurity. Failing to control for these factors may generate a spurious correlation between welfare and insecurity.

Differencing (1) to eliminate the fixed effect, we obtain a regression model of the form:

$$
\Delta \mathrm{W}_{\mathrm{it}}=\alpha \Delta \mathrm{S}_{\mathrm{it}}+\beta \Delta \mathrm{C}_{\mathrm{it}}+\Delta \varepsilon_{\mathrm{it}}
$$




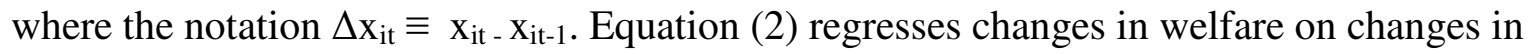
insecurity, controlling for various other effects so as to minimize omitted variable bias. Estimating (2) for various welfare indicators is the first purpose of our econometric analysis.

We also wish to investigate the channels through which insecurity may affect welfare. To do so, we examine whether insecurity is associated with a number of potential channels $\mathrm{N}_{\mathrm{it}}$ which are generally regarded as strongly related with specific dimensions of welfare. For instance, health is affected by the presence or absence of health facilities. We can therefore test whether an increase in insecurity is associated with a lower likelihood of creation of a health facility in a given location, i.e., whether:

$$
\Delta \mathrm{N}_{\mathrm{it}}=\gamma \Delta \mathrm{S}_{\mathrm{it}}+v_{\mathrm{it}}
$$

Here as before, differentiating eliminates time-invariant fixed effects that may be correlated with insecurity as well as with the presence of a health facility.

\section{The Data}

The purpose of the rest of this paper is to estimate equations (2) and (3) using comprehensive survey data on Madagascar. Madagascar constitutes a perfect test case for an investigation of insecurity and welfare. The country is quite poor, with a GDP per head of US\$260 in 2002 (World Bank, 2003). The Malagasy government estimates that $69 \%$ of the population are below the poverty line (e.g. GOM, 2003; Mistiaen, Ozler, Razafimanantena and Razafindravonona, 2002). The country is also known to have a high crime rate (Fafchamps andMoser, 2003).

A map of Madagascar with provincial and communal boundaries is shown in Figure 1. Population density is depicted in shades of grey. With a population of 16 million and a size equivalent to that of France, Belgium, and Holland combined, Madagascar has a low population density -- the median population density in each commune is 26 inhabitants per square $\mathrm{Km}$. We see that population is densest in the Central highlands around the main cities of Antananarivo (the capital city) and Antsirabe. The Eastern highlands and coast between Toamasina and Fianarantsoa are also heavily 
populated. This largely reflects climate patterns that make these areas more productive for agriculture. Other major cities such as Toamasina, Mahajanga, Toliara, and Antsiranana are coastal port cities with a small rural hinterland surrounding them. The Western and Southwestern parts of the country are more arid and much less populated.

Although Madagascar has not experienced any major armed conflict since independence, ${ }^{\text {iv }}$ insecurity is known to be a major problem. Fafchamps and Moser (2003) provide evidence that the homicide rates are comparable to that of the US in the early 1990s, when they were at its highest. Cattle rustling is a major problem in low population density area, with extremely high rates of cattle theft and the involvement of organized crime (e.g. Rasamoelina, 2000; Razafitsiamidy, 1997). Crop theft is also a commonly cited problem, and Fafchamps and Minten (2006) show an exogenous increase in poverty to be associated with a rise in crop theft.

Insecurity appears to be related to insufficient law enforcement. Ministère de la Justice (1999) and Root (1993) provide ample evidence that the legal system is not running effectively. Fafchamps and Moser (2003) show that law enforcement has no deterrent effect on crime. Survey responses suggest that, in some parts of the country, criminals who are caught do not spend any time in jail because of inefficient courts and lax prison rules. In these circumstances, we would expect insecurity to have a measurable impact on welfare.

The data on which we base our empirical analysis comes from a survey conducted by the authors in 2001. Our unit of analysis is the commune, a geographically defined administrative unit roughly equivalent to a municipality or county. Madagascar has six provinces (or faritany), which are divided into fivondronanas. The fivondronana are made up of communes -- the smallest administrative units with direct representation from the central or provincial government. Rural communes are further divided into fokontanys, which essentially represent individual villages. As of late 2001, there were approximately 1390 communes in Madagascar. ${ }^{\mathrm{v}}$

The crime statistics and other data used in this paper were all collected as part of the commune survey. The survey was conducted over a three-month period in 2001 in collaboration between Cornell University, Oxford University, and the Malagasy agricultural research institute (FOFIFA). 
A total of 1385 communes were surveyed, all but 9 currently functioning communes. ${ }^{\text {vi }}$ The remoteness of some communes and the general lack of national data on certain subjects meant that little was known about the spatial distribution of public goods and services, economic activity, or insecurity prior to the survey.

The survey was conducted at the commune's administrative center. Enumerators were instructed to gather a number of statistics from the relevant government offices in the commune. More subjective questions, such as those concerning community perceptions of existing conditions, were answered by a focus group composed of a small group of prominent residents of the commune -typically municipality officials and key informants. Crime statistics were collected only for 1999, 2000 and 2001 so as to minimize recall bias. To the best of our knowledge, there does not exist systematic time series crime data on all the municipalities of the country.

Descriptive statistics on insecurity and welfare are presented in Table 1. Focus group respondents were asked whether insecurity improved or worsened in their commune over the five years period preceding the survey. Their subjective assessment is reported in the first column of Table 1 . We see that $30 \%$ of respondents estimate that the level of insecurity in their commune improved between 1996 and 2001 while $51 \%$ estimate that it worsened. Only $19 \%$ responded that it remained unchanged.

Focus group respondents were also asked whether average income in the commune increased or fell over the same period. Responses are summarized in column 2 of Table 1. In half of the communes, respondents stated that the average income in their commune rose while $35 \%$ stated that it fell. Similar questions were asked regarding the health status of inhabitants, school enrollment, and infant mortality in the commune. The reader should keep in mind that, for the first three variables an increase is good, but for infant mortality it is bad. A majority of respondents felt that health status and school enrollment have increased, while infant mortality has decreased.

Many of the nefarious effects of insecurity depend on perceived risk and thus on perceptions of insecurity. Responses to the insecurity question therefore provide a measure of insecurity that is more economically relevant than actual crime statistics. The reader may nevertheless wonder 
whether subjective perceptions by focus group respondents bear any relationship with actual risk. To investigate this, we compare subjective perception of insecurity to crime incidence figures.

Respondents were asked to rank the security situation in their commune. Responses, presented in Table 2 , show that $28 \%$ of respondents find the security situation either bad or very bad while $25 \%$ find it good or very good. The others find it average. Recognized high crime areas have been flagged as a 'red zone' by the government; $30 \%$ of the country's communes are counted as part of the 'red zone'. Table 2 also presents stated development priorities of commune respondents. Insecurity comes third in this ranking, being the top development priority for $15 \%$ of the communes, and second priority for another $13 \%$ of communes. Insecurity is especially a concern in remote communes, a result in line with the work of Fafchamps and Moser (2003). Since remote communes also tend to be larger, when we weigh responses by area we find that insecurity is the first or second development priority in communes representing $43 \%$ of the country's area.

It is of interest to examine whether subjective assessments of insecurity are related to actual insecurity. Given the absence of civil unrest during the period under investigation, crime must the primary source of insecurity. In the second panel of Table 2 we report crime statistics collected in the commune survey. These statistics were collected separately for 1999, 2000 and 2001. Here they are averaged over the three year period 1999-2001 and reported per 100,000 inhabitants.

Of the five types of criminal activity recorded in the commune survey, cattle rustling is the most common. An average of 80 or so head of cattle are stolen on average each year in each commune -an average of 1500 or so head of cattle per 100,000 inhabitants. This figure is influenced by a number of a small number of very large outliers where cattle rustling takes place at an 'industrial' level. But the median is still 62 head of cattle reported stolen each year per 100,000 inhabitants. ${ }^{\text {vii }}$ Burglaries are the next most common type of crime, with some 43 burglaries on average per year per 100,000 inhabitants. The average number of reported homicides is higher than the high US national average from the early 1990's: 8.5 homicides per 100,000 inhabitants (Fox and Zawitz, 2000). This number is a bit higher than the 1994 national average of 6.4 intentional homicides reported in Fajnzylber et al. (1998). The median number of homicides is much lower, suggesting that crime is concentrated in certain communes. As shown by Fafchamps and Moser (2003), the 
highest homicide rates are found in isolated, less densely populated areas. The incidence of rape appears low, with less than three reported cases on average per 100,000 inhabitants. This is likely due to under-reporting bias. Vehicle theft is extremely rare, reflecting the low number of personal vehicles on the island and the fact that few people know how to drive.

To ascertain the validity of the subjective assessment of the security situation by survey respondents, we would like to regress this ranking on crime statistics. Before we do so, however, we worry that the responses given in the commune survey may be influenced in a systematic manner by the composition of the focus group. It is conceivable, for instance, that members of specific professions may be more sensitive to crime and tend to over-report it. To the extent that the composition of the focus group is correlated with location and crime, this may result in a spurious relationship. At the bottom of Table 2 we present the information we have regarding the composition of focus groups. The average number of participants is close to 9 people. Communal employees and social service workers represent over $60 \%$ of the respondents. This is unsurprising since they are likely to be the best source of quantitative information about communal affairs. There is also a non-negligible proportion of farmers and this proportion varies from focus group to focus group.

Table 3 reports an ordered probit regression of the subjective insecurity ranking on the five crime rate variables and the red zone dummy. Focus group variables are included to control, to the extent possible, for response bias. Results demonstrate that insecurity as perceived by focus group respondents largely reflects actual crime: the red zone dummy and three of the five crime variables are significant -- often at the $1 \%$ level. ${ }^{\text {viii }}$ Car theft is not significant, most probably because it is very rare. From these observations we conclude that the subjective assessment of insecurity reported by respondents is closely related with objective risk measures; it is not just driven by irrational fear and prejudice.

These results are consistent with earlier studies which have shown that, in Madagascar, perceived insecurity is significantly related to the prevalence of crime which, in the studied country, increases with isolation (Fafchamps and Moser, 2003) and poverty (Fafchamps and Minten, 2006). While in developed economies most crime occurs in urban areas, Fafchamps and Moser (2003) have shown 
that in Madagascar crime rates are higher in isolated rural areas and that much crime is associated with cattle rustling. This is confirmed in Table 3: cattle theft has a strong effect on feelings of insecurity, either directly (the coefficient of cattle theft has a $t$-value close to 8) or indirectly through the 'zone rouge' (high crime) dummy, which is exclusively rural and concentrated in high cattle theft areas. Anthropological studies of cattle theft in Madagascar document the role of organized roaming gangs that steal cattle from one commune and walk it over long distances to sell it elsewhere. Similar observations have been made for Northern Kenya by McPeak and Barrett (2001).

\section{Insecurity and Welfare}

We now examine the relationship between perceived insecurity and the four welfare measures collected in the survey -- income, access to health care, access to schooling, and infant mortality. Since all five measures compare the situation prevailing at the time of the survey with that prevailing five years earlier, they are already in differenced form, i.e., as they appear in equation (2).

Ordered probit regression results are presented in Table 4. Focus group composition variables are included as controls for possible response bias. Results show a strong negative association between an increase in insecurity over the period 1996-2001 and an improvement in income, health status, and school enrollment. Put differently, communes that experienced an increase in insecurity experienced a significantly lower increase in income, health status, or school enrollment. Infant mortality increases with insecurity but the effect is not statistically significant. These results suggest that insecurity is significantly and negatively associated with several dimensions of welfare.

The question that immediately follows is through what channel(s) this relationship occurs. Before we turn to this question, however, we must verify that the results shown in Table 4 are robust. The first possibility we investigate is the idea that both insecurity and welfare were affected by some other factor, resulting in a spurious relationship. For instance, it is conceivable that communes affected by a cyclone or a drought experienced a fall in income and a rise in insecurity, as shown 
for instance for Tanzania by Miguel (2003). To reduce the chance of such omitted variable bias, we include as additional regressors a number of variables capturing a wide variety of shocks. This approach does not entirely eliminate the risk of omitted variable bias, but it is the best we can do with the data at hand.

Shock variables are described in Table 5. Each variable measures the number of years, over the three years preceding the survey, during which a given shock or disease affected the commune. Each variable takes values from 0 (no year) to 3 (in all three years). As evidenced by Table 5, the list of shock variables is quite long as it includes climatic events (cyclone, drought, flood), plant pests and diseases (locusts, rice fleas), human diseases, and livestock diseases. Bad climatic events are a frequent occurrence, the late start of the rains being the most often cited shock. Cyclones hit the East coast of the country every year, devastating crops, causing floods, and cutting roads. Some human diseases, malaria for instance, are endemic in most of the country so there is very little variation from year to year. Others such as plague vary over time.

An additional source of concern is the possibility that disgruntled or pessimistic focus groups may respond to all questions in a negative manner. This would generate a response bias that would be common to the insecurity variable and the variables measuring changes in welfare over time. The analysis presented in Table 2 suggests that subjective perceptions about the level of insecurity correlate well with objective measures of crime, but here we are concerned about subjective perceptions about changes in insecurity. Unfortunately commune-level crime statistics going back to 1996 and before do not exist for Madagascar. Consequently we cannot conduct the same analysis as we did in Table 2 by regressing perceptions about changes in insecurity on changes in reported crime between 1996 and 2001.

We seek to address this concern by constructing two proxies for 'gripe'. Including these proxies as additional controls should reduce the omitted variable bias. We also construct our first proxy for gripe using the residual from the regression presented in Table 3. For memory, in that regression we regress the level of insecurity -- as reported by the focus group at the time of the survey -- on recent crime statistics. The error term from this regression can be taken as a proxy for the focus group's tendency to over-report insecurity. 
The second proxy we construct uses answers to focus group questions that are not directly related to welfare or insecurity but are likely to be correlated with 'gripe'. More specifically, we use answers to questions on late rains and total rainfall over the three years preceding the survey, as reported by the focus group. We combine answers to construct an index of how much the respondents complained about bad rains. We then regress this index on the value of the same index averaged over neighboring communes. The idea is that rainfall in communes nearby should be correlated with own rainfall but not with the pessimistic temperament of the respondents. Results are shown in Appendix, Table A1. The regression is highly significant, with an $\mathrm{R}^{2}$ of 0.24 . The residual from this regression measures how much more than neighboring communes the respondents complained about rainfall. This residual is a proxy for gripe if we are willing to assume that rainfall is spatially correlated -- so that rainfall in neighboring communes is a good predictor -and that gripe is distributed more or less independently across communes. While there is little doubt about the first assumption, we unfortunately have no way of verifying the second. The validity of the procedure therefore rests on this maintained assumption.

Table 6 presents ordered probit regressions of changes in welfare indicators on changes in insecurity, the composition of the focus group, the two proxies for 'gripe', and the various shock and disease variables listed in Table 5. ${ }^{\mathrm{ix}}$ We see that the insecurity coefficients retain the same sign and magnitude in all four regressions. They remain significantly negative in the first two regressions, but they are not significant in the other two. Except for one coefficient which is significant at the $10 \%$ level, the gripe variables are not significant.

Although shock and disease variables are used here only as controls, it is instructive to check whether they have the anticipated effect. We find that many climatic shocks are associated with a fall in welfare. For instance, floods, droughts, and late rains all tend to reduce income. Typhoid is associated with a fall in health status and school enrollment. Other results are more puzzling, such as the positive association between other livestock diseases and improvement in two of our welfare indicators. In this case, it is possible that higher prosperity leads households to buy, sell, and keep more livestock, thereby creating conditions favorable to epidemics. The positive association 
between plant diseases and income and health status may be due to the fact that plant diseases are more common in humid years when incomes are high.

It is conceivable that recent shocks loom larger in respondents' assessment of improvements in welfare. To investigate this possibility, we reestimate Table 6 using only shocks reported to 2001. Results, not shown here to save space, are basically identical to those reported in Table 6. We also worry that, given the high frequency of many reported shocks, they approximate average incidence rather than shock. To correct for this possibility, we regress shock measures on a large number of commune physical characteristics, such as latitude, longitude, elevation, average rainfall, and the like. The residuals from these regressions represent variation in shock variables that cannot be attributed to time-invariant characteristics. We then obtain the residuals from these regressions and use them as proxies for unanticipated shocks in Table 6. Results, not shown here to save space, yield a stronger estimated effect of the insecurity variable, which is significant not only in the income and health status regressions but also in the infant mortality regression.

As emphasized in the literature on treatment effects (e.g. Lee, 2005; Wooldridge, 2002), the results in Table 6 may be misleading if treated and untreated observations have very different values of the control variables. The linear functional form imposed by the regression framework can yield misleading results if the true slope of the treatment effect varies across communes with different characteristics (Dehejia and Wahba, 1999). To correct for this possibility, we need to compare treated and untreated communes that are comparable. Various non-parametric matching techniques have been proposed that seek to compare treated observations only to untreated observations with similar observable characteristics. One of these methods is propensity score matching, but there are more general matching methods as well.

To fit our analysis into this framework, let us define as treated those communes that suffered an increase in insecurity; those that did not are controls. Roughly half of the communes fall in each category. We report in Table 7 the results obtained using two different matching techniques. 
The first one is the nearest neighbor matching method proposed by Abadie, Drukker, Herr and Imbens (2004). To understand how this method works, say the vector of covariates is $x$. We want a measure of distance between the $x^{\prime}$ s. One easy metric is the vector norm $\left(\mathrm{x}^{\prime} \mathrm{Vx}\right)^{1 / 2}$ where $V$ is a positive definite weight matrix. The distance $\left\|\mathrm{x}_{1}-\mathrm{x}_{2}\right\|_{V}$ between two vectors $\mathrm{x}_{1}$ and $\mathrm{x}_{2}$ is then

$$
\left\|\mathrm{x}_{1}-\mathrm{x}_{2}\right\|_{V}=\left(\left(\mathrm{x}_{1}-\mathrm{x}_{2}\right)^{\prime} \mathrm{V}\left(\mathrm{x}_{1}-\mathrm{x}_{2}\right)\right)^{1 / 2}
$$

Abadie et al. (2004) recommend letting $\mathrm{V}=\mathrm{S}^{-1}$ where $\mathrm{S}$ is the covariance matrix of covariates $x$. This metric is referred to as the Mahalanobis metric. We implement this method using all the controls appearing in Table 6 as part of the covariate vector $x$.

The second set of results reported in Table 7 is based on propensity score matching. In this method, we begin by regressing treatment on the controls, the results of which are shown in Table A2 in appendix. ${ }^{\mathrm{x}}$ The predicted probability of treatment generated by this regression is called the propensity score. Rosenbaum and Rubin (1983) have shown that, as long as there is no selection on unobservables, the effect of the treatment can be consistently measured by comparing treated and untreated communes with similar propensity scores.

Estimates of the average treatment effect for our four welfare variables of interest are presented in Table 7, using common support. For propensity score matching, we use the radius method with a caliper of 0.1 as this yields the most stable results. For comparison purpose we also report results for the unmatched. Results are very similar to those reported in Table 6: both matching estimators yield a significant difference between treated and control for average income and health status, but no significant effect infant mortality and school enrollment. This confirms that the results reported in Table 6 are not an artifact of the regression framework.

There remains the possibility that the gripe variables do not fully control for response bias. The resulting measurement error in the insecurity variable may lead to endogeneity bias. In an attempt to correct for this source of bias, we seek to instrument the insecurity variable. To do this, we need to find an instrument for the change in insecurity over the years preceding the survey. We use the population census of 1993 to construct two variables that are likely to affect subsequent changes in crime but could not have been caused by it. In Madagascar, the presence of young men in the village is likely to improve the security situation. This is because rural insecurity is often due to 
gangs that attack villages to steal cattle, a point that has been emphasized repeatedly in the anthropological literature (e.g. Rasamoelina, 2000; Razafitsiamidy, 1997) and in regression analysis of crime in Madagascar (Fafchamps and Moser, 2003). Young males make communities less vulnerable to such attacks and may serve as a deterrent. ${ }^{\mathrm{xi}}$

To capture this idea, we construct a variable that measures the growth in the proportion of teenage males in the commune population. The 1993 population census report age in 5-year categories. Males aged 10 to 14 in 1993 will be between 13 and 17 in 1996 and between 18 and 22 in 2001. These are the teenage males in the recall period covered by the commune survey. Let their proportion in the population be written $S_{10-14}$. In contrast, males aged 15 to 19 in 1993 were teenagers at the time of the census but have basically become adults by the time of our recall period. Let their proportion in the population be written $S_{15-19}$. The regressor is $\Delta S=S_{10-14}-S_{15-19}$; if it is positive, there are more teenage males during the survey recall period relative to the preceding 5 year period -- and vice versa if it negative. If the presence of teenage males deters thieves, the variable should have a negative effect on insecurity: more teenage males relative to the preceding period reduces insecurity. To allow for spillover effects across communes, we use $\Delta S$ in neighboring communes as additional regressor in the propensity score regression. While this identification strategy is not ideal -- i.e., it does not rely on a controlled or quasi experimental source of variation in insecurity -- it should satisfy the exclusion restriction and it is the best we can do with the available data.

The instrumenting regression, shown in Table A3 in appendix, is basically the same as Table A2 except that it includes two more variables and is estimated using least squares. As expected, a higher proportion of young males is associated with a smaller increase in insecurity. The population variables are jointly significant but the value of the joint $F$-test is below 10, suggesting that we have a weak instrument problem.

Regression results with instrumented insecurity are shown in Table 8. Overidentification tests of the validity of the instruments fail to reject the null hypothesis that instruments are uncorrelated with the errors in the main regression. Since we have weak instruments we apply the AndersonRubin test as implemented by Moreira (2001). This procedure corrects the threshold value for the 
significance of the insecurity variable that allows for weak instruments. The results from this test are reported at the bottom of Table 8 .

Results show a massive increase in the magnitude of the insecurity coefficient (6.5 to 25 times larger). This is consistent with the presence of measurement error, uninstrumented results suffering from attenuation bias. This is hardly surprising given that subjective rankings are known to vary with mood, time of the day, and other psychological and physiological factors (e.g. Frey and Stutzer, 2002; Diener, Suh, Lucas and Smith, 1999; Layard, 2002). After instrumentation, the insecurity variable is significant with the anticipated sign in the income, health status, and infant mortality regressions. These results accord serve as an additional confirmation that the association between changes in welfare and insecurity is not simply a consequence of response bias.

\section{Possible Channels}

Having documented a robust relationship between insecurity and certain dimensions of welfare, we briefly examine possible channels through which this relationship may take place. We begin by reporting the opinion of the respondents. Each focus group was asked to provide the main cause for the change in each of the four welfare indicators. Their responses, broken into categories, are summarized in Table 9.

The most often cited cause for variation in income is a change in agricultural prices. ${ }^{\text {xii }}$ Insecurity is listed as the main reason for change in income by $8 \%$ of the communes. This is a fairly remarkable result since a change in insecurity must be quite severe before being given as the main reason for changes in income in the commune as a whole. The provision of a new health center and of a new school is given as the most important reasons for changes in health status and school enrollment, respectively. Health facilities also loom large in responses regarding infant mortality. Contrary to income, insecurity is not often listed for health status, school attendance, and infant mortality. This may be misleading, however, because insecurity may hinder or delay the construction of new schools and health centers in affected communities. 
To investigate this issue more in detail, we test whether an increase in insecurity is associated with a lower probability of attracting public services into the commune. We have information on when various infrastructures and services were first established in the studied communes. This information is summarized in Table 10 which shows the proportion of communes with the infrastructure or service in 1996 and 2001. We see that the study period witnessed a fairly large increase in the provision of secondary schools, basic health centers, and drinking water. The increase in agricultural input and output markets was less pronounced.

Based on the information presented in the first panel of Table 10, we create dummy variable that takes the value 1 if a new infrastructure or service was instituted in the commune during the 19962001 period. We then regress this dummy on the change in insecurity during the same period, as shown in equation (3). Of course, this regression is conditional on the commune not already having the infrastructure or service in 1996. We therefore estimate the model as a selection-corrected probit. Because the selection equation seeks to explain the level of infrastructure in 1996 -- not the change in the subsequent period -- we use time-invariant commune characteristics as regressors for the selection equation. To minimize selection bias in the change equation, we use a generous list of regressors including various geographical features thought to affect either the demand for public services or the cost and political desirability of providing them. The list includes longitude and latitude (major determinants of climate and thus of agricultural potential), elevation (Madagascar is a mountainous country), rainfall, temperature, soil type dummies, population density (based on the 1993 census), distance from the nearest road, and ethnic and provincial dummies. All these regressors are clearly pre-determined and most are beyond human influence. Since these regressors are not our focus of interest, we need not discuss them any further. As before, we include gripe proxies in the welfare regressions and we control for the composition of focus groups.

Regression results shown in Table 11 indicate that an increase in insecurity is associated with a lower likelihood that a secondary school or health center is built. Other public infrastructures such as drinking water and agricultural markets appear unaffected. The tentative conclusion we can draw from this and the earlier evidence is that insecurity affects welfare at least partly through lower provision of certain public services. It is worth noting that the two public services affected by insecurity, secondary schools and health centers, both require that an educated workforce (teachers, 
doctors and nurses) live in the commune or nearby. Agricultural input and output markets, in contrast, are operated by small local traders who move across markets and need not reside in the affected areas (e.g. Fafchamps and Minten, 1999; Fafchamps, Gabre-Madhin and Minten, 2005). This contrast suggests that one factor that hinders the delivery of public services to insecure areas is the difficulty to convince teachers and health workers to work and reside there.

We also have information on the number of new development projects taking place in the commune over the 1996-2001 period. As shown in Table 10, during this period the average number of new development projects per commune was 2.23 with a median of 2 . Only $19 \%$ of communes did not have a new development project during the period. We regress the (log of the) number of new development projects $(+1)$ on the change in insecurity. Results, presented in Table 12, again show a negative relationship: communes that experienced a deterioration of the security situation received fewer new development projects. The magnitude of the effect is non negligible: if the security situation worsened a bit instead of staying the same, this results in a $6 \%$ fall in the number of projects undertaken in the commune. Going from 'worsened a lot' to 'improved a lot' results in a $25 \%$ increase in the number of development projects. Given that development projects typically aim at increasing incomes and improving welfare, this evidence suggests that insecurity also lowers welfare by discouraging the placement of development projects in affected areas.

We conduct a similar analysis on manufacturing and mining employment. Results -- not shown here to save space -- show a significant negative effect of an increase in insecurity on employment growth in large manufacturing firms (more than 50 employees), but no effect on mining employment and on smaller manufacturers. To the extent that large firms depend more on sophisticated equipment and educated manpower, this again suggests that insecurity is less harmful to traditional, informal income generating activities than it is to economic activity of a more modern nature.

The survey also provides some evidence that insecurity has a negative effect on agriculture. Respondents were asked what factors hinder the expansion of cultivated acreage in lowland (irrigated) and upland (non-irrigated) areas. Insecurity was cited by $10 \%$ of respondents for lowland 
expansion and by $23 \%$ of respondents for upland expansion. ${ }^{\text {xiii }}$ Insecurity is cited more often in land-abundant communes that are more remote and where insecurity is higher.

Based on the work of Fafchamps and Minten (2006), Rasamoelina (2000), and Razafitsiamidy (1997), the fear of crop theft and of encounters with cattle thieves may be the dominant concerns of villagers. This provides yet another channel by which insecurity affects welfare: the fear of venturing too far from the village appears to discourage many farmers from expanding cultivated acreage and hence output.

\section{Conclusion}

Using original data collected by the authors, this paper has examined the relationship between insecurity and welfare. Identification of this relationship is not based on a controlled or natural experiment, so causal inference is potentially problematic and results should be interpreted in this light. We do, however, control for commune fixed effects - arguably the main cause for concern in analyses of this type. We also do our best to check the robustness of our results with respect to potential sources of bias, in particular omitted variable bias and response bias.

The results show that an increase in insecurity, as perceived by respondents, is associated with lower incomes, school enrollment, and health status, and with a higher infant mortality. This association is consistently significant for incomes and health status. For school enrollment and infant mortality, it is only significant for some estimators. Results are robust to the inclusion of shocks potentially affecting both welfare and insecurity. These findings are in contrast to those of Deininger (2003) who found no effect of crime on rural incomes in Uganda.

We then turned to the channels through which insecurity may affect welfare. We find a significant relationship between an increase in insecurity and improvements in the provision of certain public services, notably schooling and health care. We find a similar relationship with the placement of development projects. We also find some evidence that insecurity is associated with an employment reduction in large manufacturing firms - but not in mining -- and that it discourages farmers from expanding cultivated acreage. ${ }^{\text {xiv }}$ 
Taken together, the evidence suggests that insecurity is probably an important determinant of welfare in the country studied. Insecurity seems to affect welfare in many ways: through incomes via its effect on economic activity and development projects; and through access to public services by hindering the placement of social infrastructures in insecure areas. Certain types of public services -- schools and health centers -- and certain types of economic activity -- e.g., large-scale manufacturing -- appear more sensitive to insecurity than others such as mining and agricultural trade.

These findings raise the issue of why insecurity is so pervasive in Madagascar. The lax attitude of police, courts, and jail institutions appears largely responsible for this state of affairs (e.g. Root, 1993; World Bank, 1995). Fafchamps and Moser (2003), for instance, show that police presence has no deterrent effect on crime in Madagascar. Based on a survey of legal institutions in the country, the Ministère de la Justice (1999) documents many shortcomings in the implementation of existing laws. In particular, it is common for convicted criminals to be allowed out of jail in exchange for money. As a result, only petty criminals who cannot afford to pay remain in prison.

To further investigate this possibility, a question on jail effectiveness was asked to focus group respondents in a follow-up survey. ${ }^{\mathrm{xv}}$ Respondents were asked whether, if a major cattle thief were found in the commune, he would be sent to prison and would stay there. Responses, summarized in Table 13, show a sharp contrast between provinces. While the majority of respondents living in the Central highlands (Antananarivo and Fianarantsoa) believe that the thief would be sent to jail, respondents in other parts of the country -- most notably Antsiranana - overwhelmingly believe the thief would either not be convicted or, if convicted, would not serve his sentence.

These findings suggest that a major effort is long overdue to restructure and discipline the police and especially the prison institutions in Madagascar. The main focus should be organized crime, particularly cattle rustling. The evidence presented here indeed suggests that the insecurity generated by crime, especially in remote rural areas, discourages economic activity and makes it difficult to provide essential public services such as health care and schooling.

\section{References}


Abadie, A., Drukker, D., Herr, J. and Imbens, G. (2004) Implementing matching estimators for average treatment effects in Stata. Stata Journal, 4(3), pp. 290-311.

Becker, G.S. (1968) Crime and punishment: An economic approach. Journal of Political Economy, 76, pp. 169--217.

Blau, J.R. and Blau, P.M. (1982) The cost of inequality: Metropolitan structure and violent crime. American Sociological Review, 47(1), pp. 114-129.

Bourguignon, F. (2000) Crime, Violence, and Inequitable Development. The World Bank, Washington D.C., World Bank Annual Conference on Development Economics.

Clinard, M.B. and Abbott, D.J. (1973) Crime in Developing Countries (New York: John Wiley and Sons).

Collier, P. and Hoeffler, A. (1998) On economic causes of civil war. Oxford Economic Papers, 50(4), pp. 563-73.

Collier, P. and Hoeffler, A. (2002) Greed and grievances in civil war. WPS 2002-01, Center for the Study of African Economies, Oxford University.

Collier, P. and Hoeffler, A. (2004) Murder by numbers: Comparisons and inter-relationships between homicide and civil war. WPS 2004/10, Center for the Study of African Economics, Department of Economics, Oxford University.

Collier, P., Hoeffler, A. and Soderbom, M. (2004) On the duration of civil war. Journal of Peace Research, 41(3), pp. 253-73.

Cullen, J.B. and Levitt, S.D. (1999) Crime, urban flight, and the consequences for cities. Review of Economics and Statistics, 81(2), pp. 159-69.

Dehejia, R.H. and Wahba, S. (1999) Causal effects in nonexperimental studies: Reevaluating the evaluation of training programs. Journal of the American Statistical Association, 94(448), pp. 1053-62.

Deininger, K. (2003) Causes and consequences of civil strife: Micro-level evidence from Uganda. Oxford Economic Papers, 55, pp. 579-606.

Demombynes, G. and Ozler, B. (2002) Crime and local inequality in South Africa.mimeograph.

Diener, E., Suh, E.M., Lucas, R.E. and Smith, H.L. (1999) Subjective well-being: Three decades of progress. Psychology Bulletin, 125(2), pp. 276-303.

DiIulio, J.J. (1996) Help wanted: Economists, crime, and public policy. Journal of Economic Perspectives, 10, pp. 3-24. 
Ehrlich, I. (1975) On the relation between education and crime, in: F.T. Juster (ed.) Education, Income and Human Behavior, (New York: McGraw Hill), pp. 313-338.

Ehrlich, I. (1996) Crime, punishment, and the market for offenses. Journal of Economic Perspectives, 10(1), pp. 43-67.

Ehrlich, I. and Brower, G.D. (1987) On the issue of causality in the economic model of crime and law enforcement: Some theoretical considerations and experimental evidence. American Economic Review, 77(2), pp. 99-106.

Fafchamps, M., Gabre-Madhin, E. and Minten, B. (2005) Increasing returns and market efficiency in agricultural trade. Journal of Development Economics, 78, pp. 406-422.

Fafchamps, M. and Minten, B. (1999) Relationships and traders in Madagascar. Journal of Development Studies, 35(6), pp. 1-35.

Fafchamps, M. and Minten, B. (2006) Crime, transitory poverty, and isolation: Evidence from Madagascar. Economic Development and Cultural Change, 54(3), pp. 579-604.

Fafchamps, M. and Moser, C. (2003) Crime, isolation, and law enforcement. Journal of African Economies, 12(4), pp. 625-71.

Fajnzylber, P., Lederman, D. and Loayza, N. (1998) Determinants of Crime Rates in Latin American and the World. The World Bank, Washington D.C., World Bank Latin American and Caribbean Studies.

Fajnzylber, P., Lederman, D. and Loayza, N. (2000) Crime and victimization: An economic perspective. Economia, Vol. 1.1, Latin American and Caribbean Economic Association, pp. 178219.

Fajnzylber, P., Lederman, D. and Loayza, N. (2002a) Inequality and violent crime. Journal of Law and Economics, 45(1), pp. 1-40.

Fajnzylber, P., Lederman, D. and Loayza, N. (2002b) What causes violent crimes? European Economic Review, 46(7), pp. 1323-57.

Farmer, A. and Terrell, D. (2001) Crime versus justice: Is there a trade-off? Journal of Law and Economics, 44(2), pp. 345-366.

Fox, J.A. and Zawitz, M.W. (2000) Homicide Trends in the United States: 1998 Update. Crime Data Brief, Bureau of Justice Statistics, U.S. Department of Justice, http://www.ojp.usdoj.gov/bjs/.

Freeman, R.B. (1996) Why do so many young American men commit crimes and what might we do about it? Journal of Economic Perspectives, 10(1), pp. 25-42. 
Freeman, S., Grogger, J. and Sonstelie, J. (1996) The spatial concentration of crime. Journal of Urban Economics, 40(2), pp. 216-31.

Frey, B.S. and Stutzer, A. (2002) What can economists learn from happiness research? Journal of Economic Literature, XL, pp. 402-435.

Gaviria, A. and Pages, C. (2001) A pattern of crime victimization in Latin American cities. Journal of Development Economics, 67(1), pp. 181-203.

GOM (2003) Document de Stratégie pour la Réduction de la Pauvreté (Antananarivo: Government of Madagascar).

Helsley, R.W. and Strange, W.C. (1999) Gated communities and the economic geography of crime. Journal of Urban Economics, 46(1), pp. 80-105.

Layard, R. (2002) Rethinking public economics: Implications of rivalry and habit. mimeograph.

Lederman, D., Loayza, N. and Menendez, A.M. (2000) Violent crime: Does social capital matter? Technical report, World Bank.

Lee, M.J. (2005) Micro-Econometrics for Policy, Program, and Treatment Effects (Oxford: Oxford University Press).

Levitt, S. (1997) Using electoral cycles in police hiring to estimate the effect of police on crime. American Economic Review, 87, pp. 270-290.

Levitt, S. (1998) Why do Increased arrest rates appear to reduce crime: Deterrence, incapacitation, or measurement error? Economic Inquiry, 36, pp. 353-72.

Levitt, S. (1996) The effect of prison population size on crime rates: Evidence from prison overcrowding litigation. Quarterly Journal of Economics, 111(2), pp. 319-51.

Ludwig, J., Duncan, G. and Hirschfield, P. (2001) Urban poverty and juvenile crime: Evidence from a randomized housing mobility experiment. Quarterly Journal of Economics, 116(2), pp. 65579.

McPeak, J.G. and Barrett, C.B. (2001) Differential risk exposure and stochastic poverty traps among East African pastoralists. American Journal of Agricultural Economics, 83(3), pp. 674-79.

Miguel, E. (2003) Poverty and witch killing. BREAD Working Paper No. 41, Department of Economics, UC Berkeley.

Ministère de la Justice (1999) Justice selon les Justiciables: Une Enquête auprès des Usagers du Système Judiciaire. (Antananarivo : Gouvernement de Madagascar) 
Mistiaen, J.A., Ozler, B., Razafimanantena, T. and Razafindravonona, J. (2002) Putting welfare on the map in Madagascar. African Region Working Paper No. 34, World Bank.

Moreira, M. (2001) Tests with correct size when instruments can be arbitrarily weak. Center for Labor Economics Working Paper 37, UC Berkeley.

Morgan, K. (2000) Inequality and crime. Review of Economics and Statistics, 82(4), pp. 530-539.

Pradhan, M. and Ravallion, M. (1999) Demand for public safety. Policy Research Working Paper 2043, World Bank.

Ramiarantsoa, H. (1995) Chair de la Terre, Oeil de l'Eau: Paysannerie et Recomposition des Campagnes en Imerina (Madagascar) (Paris : ORSTOM Editions).

Raphael, S. and Winter-Ember, R. (2001) Identifying the effect of unemployment on crime. Journal of Law and Economics, 44(1), pp. 259-83.

Rasamoelina, H. (2000) Etat, Communautés Villageoises et Banditisme Rural : L'exemple du Vol de Boeufs dans la Haute-Matsiatra, Madagascar (Perpignan : Université de Perpignan).

Razafitsiamidy, A. (1997) Le vol de boeufs dans le sud de Madagascar. Etudes Africaines, INALCO, Paris, Ph.D. Thesis.

Rivers, D. and Vuong, Q. (1988) Limited information estimators and exogeneity tests for simultaneous probit models. Journal of Econometrics, 39, pp. 347-66.

Root, H. (1993), Environment for investment in Madagascar: Institutional reform for market economy. Country Report No. 11, Center for Institutional Reform and the Informal Sector, University of Maryland at College Park.

Rosenbaum, P.R. and Rubin, D.B. (1983) The central role of the propensity score in observational studies for causal effect. Biometrika, 70(1), pp. 41-55.

Sah, R.K. (1991) Social osmosis and patterns of crime. Journal of Political Economy, 99(6), pp. 1272-95.

Smith, K., Barrett, C.B. and Box, P.W. (2001) Not necessarily in the same boat: Heterogeneous risk assessment among East African pastoralists. Journal of Development Studies, 37(5), pp. 1-30.

Smith, R. and Blundell, R. (1986) An exogeneity test for a simultaneous equation Tobit model with an application to labor supply. Econometrica, 54, pp. 679-685.

Soares, R. (2004) Development, crime and punishment: Accounting for the international difference in crime rates. Journal of Development Economics, 73(1), pp. 155-184. 
Wilson, M., Daly, M. and Pound, N. (2002) An evolutionary psychological perspective on the modulation of competitive confrontation and risk-taking, in: D. Pfaff et al. (eds.) Hormones, Brain and Behavior, Vol. 5, (San Diego: Academic Press), pp. 381-408.

World Bank (1995) Madagascar: New horizons - Building a strategy for private sector, export-led growth: A private sector assessment. Report No. 14385-MAG, World Bank.

World Bank (2003) World Bank Development Report: Sustainable Development in a Dynamic World (Washington DC: The World Bank).

Wooldridge, J.M. (2002) Econometric Analysis of Cross Section and Panel Data (Cambridge: MIT Press). 
Table 1: Evolution of insecurity and welfare

\begin{tabular}{|c|c|c|c|c|c|}
\hline \multirow[b]{2}{*}{$\begin{array}{l}\text { Percentage of } \\
\text { responses }\end{array}$} & \multicolumn{5}{|c|}{ Evolution compared to five years ago } \\
\hline & $\begin{array}{l}\text { Level of } \\
\text { insecurity } \\
\text { in commune }\end{array}$ & $\begin{array}{l}\text { Average } \\
\text { income } \\
\text { of inhab. }\end{array}$ & $\begin{array}{l}\text { Health } \\
\text { status } \\
\text { of inhab. }\end{array}$ & $\begin{array}{c}\text { School } \\
\text { enrollment } \\
\text { in commune }\end{array}$ & $\begin{array}{c}\text { Infant } \\
\text { mortality } \\
\text { in commune }\end{array}$ \\
\hline Increased a lot & $3 \%$ & $10 \%$ & $12 \%$ & $14 \%$ & $4 \%$ \\
\hline Increased a bit & $27 \%$ & $40 \%$ & $61 \%$ & $55 \%$ & $20 \%$ \\
\hline Stayed the same & $19 \%$ & $15 \%$ & $16 \%$ & $14 \%$ & $17 \%$ \\
\hline Decreased a bit & $39 \%$ & $28 \%$ & $7 \%$ & $12 \%$ & $46 \%$ \\
\hline Decreased a lot & $12 \%$ & $7 \%$ & $5 \%$ & $4 \%$ & $12 \%$ \\
\hline Total & $100 \%$ & $100 \%$ & $100 \%$ & $100 \%$ & $100 \%$ \\
\hline No of valid observations & 1379 & 1351 & 1349 & 1347 & 1294 \\
\hline
\end{tabular}


Table 2: Crime and insecurity statistics
A. Perceptions of insecurity by communal focus groups
Percentage of responses
Very bad
Bad
Average
Good
Very good
Total
Yes $=1$

\section{Agriculture}
2. Roads
3. Insecuity
4. Health
5. Education
6. Water
7. Environment
Total
Level of insecurity in the commune

$$
\begin{array}{r}
9 \% \\
19 \% \\
47 \% \\
21 \% \\
4 \%
\end{array}
$$
$100 \%$
Communes in 'red zone'
$30 \%$
Stated first priority for development
$27 \%$
$26 \%$
$15 \%$
$14 \%$
$10 \%$
$6 \%$
$2 \%$
$100 \%$

No of valid observations

1379

\section{B. Crime statistics}

All figures reported in number of cases per year and per 100,000 inhabitants

Number of stolen cattle

Number of stolen vehicles

Mean

1496.0

Number of burglaries

0.2

Median

62.0

0.0

Std. dev.

Number of homicides

42.8

7.9

Number of rapes

8.5

2.1

2.9

0.0

97

Composition of focus groups

Average number of participants

8.6

Occupation:

Communal employees

Social/public service employees

Village (fokontany) heads

Farmers

$40 \%$

$21 \%$

Others

$6 \%$

$14 \%$

$19 \%$ 
Table 3: Link subjective and objective insecurity measures ordered probit regression

Crime
Nomm. within "zone rouge"
Number of stolen cattle annually
Number of homicides annually
Number of burglaries annually
Number of rapes annually
Composition of focus group
size of the group
number of communal employees
number of social/public employees
number of village leaders
number of farmers
Province dummies
cutoff points
1
2
3
4

$\begin{array}{lrr}\text { Unit } & \text { Coefficient } & \text { Z-value } \\ \text { yes }=1 & -1.001 & \mathbf{- 1 0 . 6 0} \\ \log (x+1) & -0.110 & \mathbf{- 7 . 9 1} \\ \log (x+1) & 0.001 & 0.00 \\ \log (x+1) & -0.068 & \mathbf{- 2 . 1 9} \\ \log (x+1) & -0.089 & \mathbf{- 4 . 5 1} \\ \log (x+1) & -0.035 & -0.89\end{array}$

$\begin{array}{lll}\log (\mathrm{x}) & 0.022 & 0.17\end{array}$

share $\quad 0.121 \quad 0.50$

share $\quad 0.073 \quad 0.29$

share $\quad 0.279 \quad 0.71$

share $\quad 0.065 \quad 0.21$

Number of observations $\quad 1362$

$\begin{array}{ll}\text { Pseudo R2 } & 0.15\end{array}$

Dependent variable takes values from 1 (very bad) to 5 (very good)

Crime statistics: average of three preceding years 
Table 4: Ordered probit regressions of welfare indicators on insecurity

\begin{tabular}{|c|c|c|c|c|c|c|c|c|}
\hline \multirow[b]{3}{*}{ Insecurity } & \multicolumn{8}{|c|}{ Changes in: } \\
\hline & \multicolumn{2}{|c|}{ Average income } & \multicolumn{2}{|c|}{ Health status } & \multicolumn{2}{|c|}{ School enrollment } & \multicolumn{2}{|c|}{ Child mortality } \\
\hline & Coef. & z-stat. & Coef. & z-stat. & Coef. & z-stat. & Coef. & z-stat. \\
\hline Increase in insecurity & -0.181 & -3.10 & -0.171 & -2.80 & -0.116 & -1.94 & 0.085 & 1.41 \\
\hline \multicolumn{9}{|l|}{ Composition of focus group } \\
\hline Size of the group (in log) & -0.183 & -1.84 & 0.028 & 0.28 & 0.238 & 2.38 & -0.248 & -2.46 \\
\hline Share communal employees & 0.210 & 0.93 & 0.080 & 0.34 & 0.039 & 0.17 & 0.328 & 1.39 \\
\hline Share social/public employees & 0.270 & 1.05 & 1.180 & 4.38 & 0.619 & 2.34 & 0.254 & 0.94 \\
\hline Share village leaders & 0.352 & 0.87 & 0.031 & 0.07 & -0.705 & -1.71 & -0.454 & -1.09 \\
\hline Share farmers & -0.099 & -0.34 & 0.217 & 0.72 & 0.177 & 0.60 & -0.219 & -0.72 \\
\hline \multicolumn{9}{|l|}{ Cutoff points } \\
\hline 1 & -1.804 & -2.39 & -1.399 & -2.00 & -1.151 & -1.74 & -1.502 & -2.10 \\
\hline 2 & -0.686 & -1.27 & -0.918 & -1.52 & -0.396 & -0.98 & -0.106 & -0.70 \\
\hline 3 & -0.303 & -0.88 & -0.308 & -0.90 & 0.075 & -0.51 & 0.381 & -0.21 \\
\hline 4 & 0.995 & 0.41 & 1.503 & 0.90 & 1.651 & 1.06 & 1.457 & 0.85 \\
\hline Number of observations & 1343 & & 1341 & & 1339 & & 1286 & \\
\hline Pseudo R2 & 0.0060 & & 0.0117 & & 0.0069 & & 0.0063 & \\
\hline
\end{tabular}

Each dependent variable takes values from 1 (worsened a lot) to 5 (improved a lot)

The insecurity variable takes values from 1 (improved a lot) to 5 (worsened a lot). 
Table 5: Descriptive statistics for diseases and shocks

\begin{tabular}{lrr}
\hline Climatic and agricultural shocks & Mean & Std. Dev \\
Cyclone & 0.6 & 0.80 \\
Flood & 1.2 & 1.16 \\
Broken bridge or cut road & 1.2 & 1.29 \\
Drought & 1.0 & 1.17 \\
Rice fleas & 1.1 & 1.36 \\
Phytosanitary diseases & 1.7 & 1.42 \\
Frost & 0.4 & 0.85 \\
Locusts & 0.8 & 0.87 \\
Late start of rains & 1.4 & 1.16 \\
Human diseases & & \\
Malaria & 2.8 & 0.78 \\
Tuberculosis & 1.7 & 1.39 \\
Typhoid & 1.0 & 1.31 \\
Cholera & 0.5 & 0.83 \\
Plague & 0.3 & 0.77 \\
Livestock diseases & & \\
Distomatosis & 2.5 & 1.07 \\
Maladie du charbon bacterien & 1.3 & 1.41 \\
Maladie du charbon symptomatique & 1.9 & 1.33 \\
Pig plague & 1.6 & 1.28 \\
Newcastle disease (chicken) & 2.7 & 0.87 \\
Other livestock epidemic & 0.7 & 1.22 \\
Number of valid observations & & \\
\hline Each variabe measures the & 1378 &
\end{tabular}

Each variable measures the number of years the commune was affected by a shock or disease in the three years preceding the survey. 
Table 6: Ordered probit regressions with additional controls

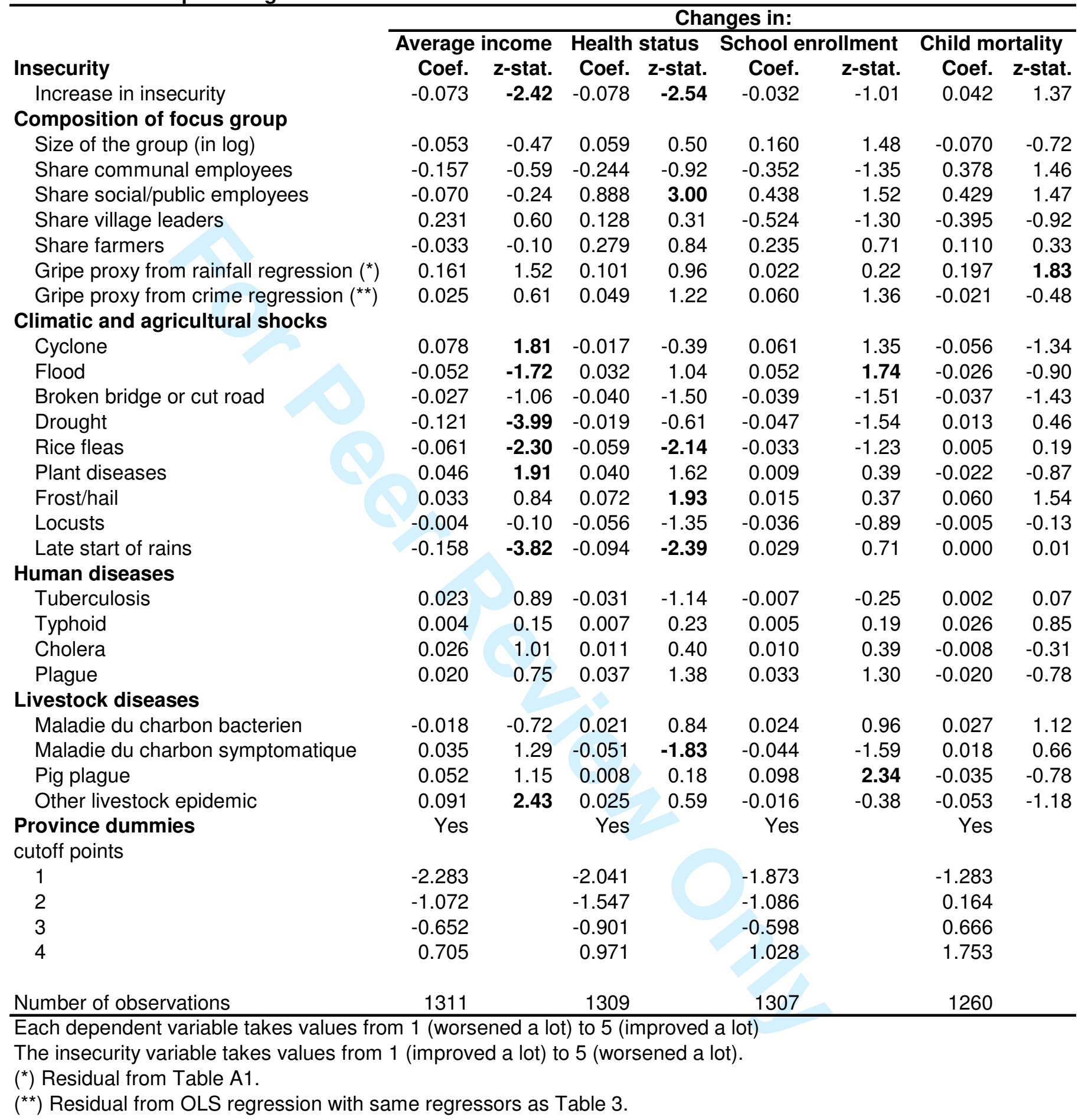




\begin{tabular}{|c|c|c|c|c|c|}
\hline Average income & \#Treated & \#Controls & Difference & S.E. & T-stat \\
\hline Unmatched & 655 & 672 & -0.220 & 0.062 & -3.50 \\
\hline Matched -- Nearest neighbor $\left(^{*}\right)$ & 646 & 665 & -0.133 & 0.072 & -1.84 \\
\hline Matched -- PS Radius $\left({ }^{\star *}\right)$ & 646 & 664 & -0.141 & 0.066 & -2.13 \\
\hline \multicolumn{6}{|l|}{ Health status } \\
\hline Unmatched & 652 & 673 & -0.167 & 0.051 & -3.26 \\
\hline Matched -- Nearest neighbor $\left({ }^{*}\right)$ & 643 & 666 & -0.136 & 0.063 & -2.16 \\
\hline Matched -- PS Radius $\left({ }^{* *}\right)$ & 643 & 665 & -0.154 & 0.053 & -2.88 \\
\hline \multicolumn{6}{|l|}{ School enrollment } \\
\hline Unmatched & 650 & 672 & -0.113 & 0.056 & -2.03 \\
\hline Matched -- Nearest neighbor $\left({ }^{*}\right)$ & 642 & 665 & -0.016 & 0.070 & -0.23 \\
\hline Matched -- PS Radius ( $\left.{ }^{\star \star}\right)$ & 642 & 663 & -0.094 & 0.059 & -1.59 \\
\hline \multicolumn{6}{|l|}{ Infant mortality } \\
\hline Unmatched & 620 & 652 & 0.049 & 0.060 & 0.08 \\
\hline Matched -- Nearest neighbor $\left({ }^{*}\right)$ & 612 & 648 & 0.015 & 0.070 & 0.21 \\
\hline Matched -- PS Radius $\left({ }^{* *}\right)$ & 612 & 646 & 0.060 & 0.062 & 0.96 \\
\hline
\end{tabular}

$\left(^{*}\right)$ Nearest neighbor matching using a Mahalanobis matrix on the complete $X$ vector (nnmatch stata commanc $\left({ }^{* *}\right)$ Propensity score matching using radius method, caliper $=0.1$ (attr stata command) 
Table 8. IV regressions of welfare indicators on insecurity

\begin{tabular}{|c|c|c|c|c|c|c|c|c|}
\hline \multirow[b]{3}{*}{ Insecurity } & \multicolumn{8}{|c|}{ Changes in: } \\
\hline & \multicolumn{2}{|c|}{ Average income } & \multicolumn{2}{|c|}{ Health status } & \multicolumn{2}{|c|}{ School enrollment } & \multicolumn{2}{|c|}{ Child mortality } \\
\hline & Coef. & z-stat. & Coef. & z-stat. & Coef. & z-stat. & Coef. & z-stat. \\
\hline Increase in insecurity (instrumented) & $-2.478^{* *}$ & -2.548 & $-1.282^{\star \star}$ & -2.083 & -1.048 & -1.551 & $1.906^{\star *}$ & 2.154 \\
\hline \multicolumn{9}{|l|}{ Composition of focus group } \\
\hline Size of the group (in log) & 0.035 & 0.197 & 0.104 & 0.871 & 0.189 & 1.502 & -0.157 & -0.988 \\
\hline Share communal employees & 0.069 & 0.186 & 0.072 & 0.282 & -0.066 & -0.248 & 0.124 & 0.363 \\
\hline Share social/public employees & -0.341 & -0.793 & $0.709^{\star \star}$ & 2.421 & 0.389 & 1.261 & 0.634 & 1.606 \\
\hline Share village leaders & -0.440 & -0.666 & -0.134 & -0.300 & -0.780 & -1.620 & 0.121 & 0.200 \\
\hline Share farmers & 0.833 & 1.472 & $0.755^{\star \star}$ & 2.019 & $0.684^{\star}$ & 1.707 & -0.574 & -1.132 \\
\hline Gripe proxy from rainfall regression $\left({ }^{*}\right)$ & 0.244 & 1.597 & 0.118 & 1.139 & 0.029 & 0.268 & 0.184 & 1.339 \\
\hline Gripe proxy from crime regression $\left({ }^{* *}\right)$ & $-0.287^{*}$ & -1.956 & -0.117 & -1.216 & -0.090 & -0.872 & $0.246^{\star}$ & 1.808 \\
\hline \multicolumn{9}{|l|}{ Climatic and agricultural shocks } \\
\hline Cyclone & 0.007 & 0.097 & -0.060 & -1.296 & 0.021 & 0.436 & 0.005 & 0.081 \\
\hline Flood & -0.027 & -0.593 & 0.031 & 1.020 & $0.063^{\star *}$ & 1.969 & -0.048 & -1.195 \\
\hline Broken bridge or cut road & -0.015 & -0.404 & -0.018 & -0.690 & -0.028 & -1.041 & $-0.059^{*}$ & -1.716 \\
\hline Drought & -0.033 & -0.589 & 0.035 & 0.961 & -0.009 & -0.231 & -0.067 & -1.266 \\
\hline Rice fleas & $-0.113^{\star \star \star}$ & -2.691 & $-0.076^{\star \star \star}$ & -2.702 & -0.044 & -1.461 & 0.045 & 1.166 \\
\hline seases & 0.053 & 1.544 & 0.027 & 1.152 & 0.010 & 0.398 & -0.016 & -0.513 \\
\hline Frost & 0.015 & 0.264 & 0.051 & 1.336 & 0.005 & 0.115 & 0.069 & 1.397 \\
\hline Locusts & -0.062 & -0.976 & $-0.083^{*}$ & -1.904 & -0.052 & -1.151 & 0.041 & 0.694 \\
\hline Late start of rains & $-0.223^{\star \star \star}$ & -3.512 & $-0.102^{\star \star}$ & -2.401 & 0.005 & 0.104 & 0.042 & 0.724 \\
\hline \multicolumn{9}{|l|}{ Human diseases } \\
\hline Tuberculosis & 0.019 & 0.493 & 0.024 & 0.933 & 0.032 & 1.144 & -0.012 & -0.347 \\
\hline Typhoid & 0.023 & 0.615 & $-0.057^{\star \star}$ & -2.188 & -0.042 & -1.564 & 0.030 & 0.893 \\
\hline Cholera & 0.023 & 0.349 & 0.000 & 0.009 & $0.085^{\star}$ & 1.829 & 0.005 & 0.092 \\
\hline Plague & 0.052 & 0.840 & 0.004 & 0.086 & -0.015 & -0.340 & -0.015 & -0.272 \\
\hline \multicolumn{9}{|l|}{ Livestock diseases } \\
\hline Maladie du charbon bacterien & 0.002 & 0.061 & -0.033 & -1.288 & -0.019 & -0.735 & 0.006 & 0.190 \\
\hline Maladie du charbon symptomatique & 0.062 & 1.324 & 0.041 & 1.334 & 0.032 & 0.978 & -0.017 & -0.390 \\
\hline Pig plague & 0.062 & 1.550 & 0.027 & 0.999 & 0.021 & 0.754 & -0.033 & -0.939 \\
\hline Other livestock epidemic & -0.006 & -0.150 & 0.020 & 0.757 & 0.024 & 0.881 & -0.003 & -0.088 \\
\hline dummies & Yes & & Yes & & Yes & & Yes & \\
\hline Intercept & $4.238^{\star \star \star}$ & 7.995 & $3.909^{\star \star *}$ & 10.951 & $3.713^{* \star *}$ & 9.871 & $2.419^{\star \star \star *}$ & 5.109 \\
\hline \multirow{3}{*}{ Overidentification test } & Ch-sq(1) & $p$-value & Ch-sq(1) & p-value & Ch-sq(1) & $p$-value & Ch-sq(1) & $p$-value \\
\hline & 0.161 & 0.688 & 0.064 & 0.800 & 0.127 & 0.721 & 0.002 & 0.967 \\
\hline & test value & $95 \%$ crit. & test value & $95 \%$ crit. & test value & $95 \%$ crit. & test value & $95 \%$ crit. \\
\hline Anderson-Rubin test & 13.9213 & 5.992 & 6.1229 & 5.992 & 3.1942 & 5.992 & 8.1227 & 5.992 \\
\hline
\end{tabular}


Table 9: Stated reasons by focus groups for evolution in welfare

\begin{tabular}{|c|c|c|c|c|c|c|c|c|}
\hline \multirow[b]{2}{*}{$\begin{array}{l}\text { Percentage of } \\
\text { responses }\end{array}$} & \multicolumn{8}{|c|}{ Evolution compared to five years ago } \\
\hline & \multicolumn{2}{|c|}{$\begin{array}{l}\text { Average income } \\
\text { of inhabitants } \\
\text { Decrease Increase }\end{array}$} & \multicolumn{2}{|c|}{$\begin{array}{c}\text { Health status } \\
\text { of inhabitants } \\
\text { Decrease Increase }\end{array}$} & \multicolumn{2}{|c|}{$\begin{array}{l}\text { School enrollment } \\
\text { in commune } \\
\text { Decrease Increase }\end{array}$} & \multicolumn{2}{|c|}{$\begin{array}{l}\text { Infant mortality } \\
\text { in commune } \\
\text { Decrease Increase }\end{array}$} \\
\hline Climatic or environmental shock & $10 \%$ & $1 \%$ & $1 \%$ & $0 \%$ & $1 \%$ & $0 \%$ & $0 \%$ & $0 \%$ \\
\hline Improvement/degradation security & $8 \%$ & $8 \%$ & $1 \%$ & $1 \%$ & $3 \%$ & $1 \%$ & $1 \%$ & $1 \%$ \\
\hline End/start of project from govt ou NGO & $1 \%$ & $6 \%$ & $1 \%$ & $3 \%$ & $1 \%$ & $2 \%$ & $5 \%$ & $3 \%$ \\
\hline Loss of jobs/beneficiary from industrialization & $1 \%$ & $2 \%$ & $0 \%$ & $0 \%$ & $0 \%$ & $0 \%$ & $0 \%$ & $0 \%$ \\
\hline Change in access in transport & $3 \%$ & $2 \%$ & $0 \%$ & $0 \%$ & $0 \%$ & $0 \%$ & $0 \%$ & $0 \%$ \\
\hline Change in ag. income due to change in prices & $61 \%$ & $53 \%$ & $10 \%$ & $1 \%$ & $8 \%$ & $2 \%$ & $1 \%$ & $3 \%$ \\
\hline Change in non-farm income & $4 \%$ & $10 \%$ & $0 \%$ & $0 \%$ & $0 \%$ & $0 \%$ & $0 \%$ & $0 \%$ \\
\hline Change in wage labor & $2 \%$ & $3 \%$ & $1 \%$ & $0 \%$ & $0 \%$ & $0 \%$ & $0 \%$ & $0 \%$ \\
\hline Closing/opening of schools & $0 \%$ & $0 \%$ & $1 \%$ & $0 \%$ & $42 \%$ & $61 \%$ & $1 \%$ & $1 \%$ \\
\hline Closing/opening of health centers & $0 \%$ & $0 \%$ & $48 \%$ & $67 \%$ & $1 \%$ & $1 \%$ & $46 \%$ & $57 \%$ \\
\hline Change in school costs & $0 \%$ & $0 \%$ & $0 \%$ & $1 \%$ & $17 \%$ & $15 \%$ & $2 \%$ & $0 \%$ \\
\hline Change in health costs & $1 \%$ & $0 \%$ & $17 \%$ & $14 \%$ & $0 \%$ & $0 \%$ & $22 \%$ & $16 \%$ \\
\hline Others & $10 \%$ & $13 \%$ & $19 \%$ & $13 \%$ & $27 \%$ & $16 \%$ & $22 \%$ & $19 \%$ \\
\hline Total & $100 \%$ & $100 \%$ & $100 \%$ & $100 \%$ & $100 \%$ & $100 \%$ & $100 \%$ & $100 \%$ \\
\hline Number of observations & 479 & 674 & 156 & 979 & 226 & 931 & 762 & 311 \\
\hline
\end{tabular}


Table 10: Infrastructure, services and projects

\begin{tabular}{lrr}
\hline Percentage of communes with: & In 1996 & In 2001 \\
Secondary school & $46 \%$ & $53 \%$ \\
Basic health center & $65 \%$ & $94 \%$ \\
Drinking water (government and non-governmental) & $25 \%$ & $39 \%$ \\
Seller of agricultural inputs & $10 \%$ & $17 \%$ \\
Agricultural market & $32 \%$ & $37 \%$ \\
\hline New development projects since 1996: & Mean & Median \\
Average number per commune & 2.23 & 2 \\
\% of communes where there were none & $19 \%$ & \\
& & \\
Number of observations & 1383 & \\
\hline
\end{tabular}


Table 11: Probit regressions with selection correction

\begin{tabular}{|c|c|c|c|c|c|c|c|c|c|c|}
\hline \multirow{3}{*}{ Change in 1996-2001 period } & \multicolumn{2}{|c|}{$\begin{array}{l}\text { Construction of } \\
\text { school }\end{array}$} & \multicolumn{2}{|c|}{$\begin{array}{l}\text { Construction of } \\
\text { health center }\end{array}$} & \multicolumn{2}{|c|}{$\begin{array}{c}\text { Provision of } \\
\text { drinking water }\end{array}$} & \multicolumn{2}{|c|}{$\begin{array}{c}\text { New market for } \\
\text { agricultural output }\end{array}$} & \multicolumn{2}{|c|}{$\begin{array}{l}\text { New supplier of } \\
\text { agricultural inputs }\end{array}$} \\
\hline & Coef. & z-stat. & Coef. & z-stat. & Coef. & z-stat. & Coef. & z-stat. & Coef. & z-stat. \\
\hline & -0.110 & -2.12 & -0.108 & -2.15 & -0.013 & -0.32 & 0.017 & 0.27 & 0.018 & 0.35 \\
\hline \multicolumn{11}{|l|}{ Composition of focus group } \\
\hline Size of the group (in log) & 0.132 & 0.96 & -0.131 & -0.76 & 0.100 & 0.59 & 0.206 & 1.05 & -0.308 & -1.86 \\
\hline Share communal employees & 0.275 & 0.58 & -0.433 & -0.92 & 0.284 & 0.81 & -0.037 & -0.08 & -0.441 & -1.01 \\
\hline Share social/public employees & 0.740 & 1.55 & 2.043 & 3.03 & 0.516 & 1.32 & -0.437 & -0.80 & 0.425 & 0.87 \\
\hline Share village leaders & 0.643 & 0.87 & -0.402 & -0.48 & -0.164 & -0.28 & -0.886 & -0.81 & -0.008 & -0.01 \\
\hline Share farmers & -0.876 & -1.42 & -1.525 & -2.73 & -0.321 & -0.73 & 0.190 & 0.40 & -0.955 & -1.68 \\
\hline Gripe proxy from rainfall regression $\left(^{*}\right)$ & 0.081 & 0.63 & 0.129 & 0.79 & 0.031 & 0.30 & 0.117 & 0.86 & -0.020 & -0.16 \\
\hline Gripe proxy from crime regression $\left({ }^{\star \star}\right)$ & -0.045 & -0.60 & -0.117 & -1.28 & 0.050 & 0.84 & -0.006 & -0.08 & 0.042 & 0.63 \\
\hline Intercept & -1.702 & -3.29 & 2.306 & 3.93 & -1.423 & -2.80 & -2.047 & -3.44 & -0.678 & -1.26 \\
\hline \multicolumn{11}{|l|}{ Selection equation: no service in 1996} \\
\hline Longitude & 0.033 & 0.65 & -0.079 & -1.56 & -0.093 & -1.54 & 0.155 & 2.80 & -0.063 & -0.56 \\
\hline Latitude & -0.159 & -3.16 & -0.068 & -1.31 & -0.026 & -0.40 & 0.067 & 1.24 & 0.015 & 0.18 \\
\hline Mean elevation & 0.000 & 0.34 & 0.000 & 0.12 & 0.000 & 0.20 & 0.000 & 0.58 & -0.001 & -0.42 \\
\hline Mean elevation squared & 0.000 & 0.90 & 0.000 & 0.22 & 0.000 & 0.25 & 0.000 & -1.37 & 0.000 & -1.49 \\
\hline Mean rainfall & 0.000 & 0.27 & -0.001 & -2.28 & 0.000 & 0.66 & -0.001 & -1.02 & 0.000 & 0.07 \\
\hline Mean rainfall squared & 0.000 & -0.35 & 0.000 & 1.96 & 0.000 & -0.37 & 0.000 & 0.95 & 0.000 & 0.25 \\
\hline Mean temperature & 0.060 & 0.91 & 0.047 & 0.73 & -0.126 & -1.72 & -0.126 & -1.77 & -0.182 & -1.89 \\
\hline Mean temperature squared & 0.000 & -0.63 & 0.000 & -0.72 & 0.000 & 2.06 & 0.000 & 1.71 & 0.000 & 1.45 \\
\hline Soil type 2 & 0.000 & -0.13 & -0.003 & -1.18 & 0.008 & 3.28 & 0.002 & 0.99 & 0.000 & 0.03 \\
\hline Soil type 3 & -0.001 & -0.20 & -0.006 & -1.41 & 0.005 & 1.27 & 0.002 & 0.41 & -0.008 & -1.53 \\
\hline Soil type 4 & 0.002 & 0.77 & -0.001 & -0.57 & 0.007 & 2.73 & 0.007 & 2.86 & 0.010 & 2.21 \\
\hline Soil type 5 & 0.008 & 2.82 & 0.005 & 1.93 & 0.008 & 2.56 & 0.002 & 0.78 & 0.015 & 2.40 \\
\hline Soil type 6 & 0.006 & 2.21 & 0.000 & -0.10 & 0.009 & 2.89 & 0.005 & 1.68 & 0.001 & 0.18 \\
\hline Soil type 7 & -0.001 & -0.41 & -0.002 & -0.84 & 0.005 & 2.05 & -0.002 & -0.64 & -0.004 & -1.10 \\
\hline Log of population density & -0.257 & -5.98 & 0.047 & 1.21 & -0.222 & -4.84 & -0.245 & -5.78 & -0.293 & -5.23 \\
\hline Log of travel time to nearest town & 0.058 & 1.42 & -0.079 & -1.95 & 0.227 & 4.54 & 0.074 & 1.61 & 0.150 & 2.03 \\
\hline Forest ethnic groups & 0.004 & 1.61 & -0.006 & -2.67 & 0.000 & 0.14 & 0.001 & 0.50 & 0.013 & 1.97 \\
\hline Livestock raising ethnic groups & -0.001 & -0.39 & -0.002 & -1.33 & 0.000 & 0.11 & -0.001 & -0.27 & 0.001 & 0.16 \\
\hline Western ethnic groups & -0.003 & -0.92 & -0.007 & -2.33 & -0.006 & -1.69 & 0.004 & 1.25 & 0.006 & 1.11 \\
\hline Eastern ethnic groups & 0.002 & 0.72 & 0.002 & 0.99 & 0.002 & 0.69 & 0.004 & 1.80 & 0.006 & 1.70 \\
\hline Size of the group (in log) & -0.242 & -1.63 & -0.022 & -0.15 & 0.487 & 2.80 & 0.274 & 1.73 & -0.350 & -1.89 \\
\hline Share communal employees & -0.392 & -1.28 & -0.197 & -0.66 & 0.413 & 1.25 & 0.525 & 1.68 & -0.357 & -0.75 \\
\hline Share social/public employees & -1.402 & -4.16 & -0.261 & -0.76 & -0.022 & -0.06 & -0.220 & -0.62 & -1.537 & -2.91 \\
\hline Share village leaders & 1.531 & 2.85 & -0.094 & -0.18 & 1.035 & 1.71 & 2.614 & 4.43 & 1.620 & 2.06 \\
\hline Share farmers & 0.039 & 0.10 & 0.299 & 0.79 & 1.373 & 3.08 & 0.554 & 1.42 & 0.519 & 0.76 \\
\hline Gripe proxy from rainfall regression $\left({ }^{*}\right)$ & 0.112 & 1.27 & 0.194 & 2.11 & 0.101 & 0.97 & -0.154 & -1.68 & -0.252 & -1.93 \\
\hline Gripe proxy from crime regression ${ }^{* *}$ & 0.029 & 0.61 & -0.024 & -0.51 & 0.019 & 0.33 & 0.007 & 0.15 & -0.078 & -1.14 \\
\hline Province dummies & \multicolumn{10}{|c|}{ Included but not shown } \\
\hline Intercept & -0.545 & -0.08 & 0.712 & 0.11 & 11.207 & 1.46 & 8.131 & 1.06 & 26.279 & 2.58 \\
\hline Number of uncensored observations & 701 & & 459 & & 990 & & 890 & & 1171 & \\
\hline
\end{tabular}


Table 12: Development projects started up over the last five years

\begin{tabular}{lrr}
\hline Change in 1996-2001 period & Coef. & z-stat. \\
$\quad$ Increase in insecurity & -0.071 & $\mathbf{- 4 . 3 3}$ \\
Composition of focus group & & \\
$\quad$ Size of the group (in log) & 0.279 & $\mathbf{4 . 9 7}$ \\
Share communal employees & -0.090 & -0.73 \\
Share social/public employees & -0.028 & -0.20 \\
Share village leaders & -1.034 & $\mathbf{- 4 . 5 0}$ \\
Share farmers & -0.237 & -1.45 \\
Gripe proxy from rainfall regression $\left({ }^{*}\right)$ & -0.049 & -1.13 \\
Gripe proxy from crime regression $\left(^{* *}\right)$ & -0.019 & -0.81 \\
Intercept & 0.731 & $\mathbf{4 . 2 0}$
\end{tabular}

Number of observations $\quad 1360$

Dependent variable is log(number of new development projects +1 )

(*) Residual from Table A1.

$\left.{ }^{(* *}\right)$ Residual from OLS regression with same regressors as Table 3. 


\section{Table 13: Confidence in the justice system}

Answer to hypothetical question:

"Suppose that a famous cattle thief is caught, will he be sent to prison and will he stay there?"

Antananarivo

Fianarantsoa

Toamasina

Mahajanga

Toliara

Antsiranana

Madagascar

Number of valid observations

\begin{tabular}{rr} 
Very sure & \multicolumn{1}{c}{ Sure } \\
$46 \%$ & $42 \%$ \\
$17 \%$ & $37 \%$ \\
$37 \%$ & $19 \%$ \\
$21 \%$ & $8 \%$ \\
$8 \%$ & $25 \%$ \\
$0 \%$ & $12 \%$
\end{tabular}

$22 \% \quad 24 \%$

Maybe

\section{Probably not}

$12 \%$

$17 \%$

$11 \%$

$54 \%$

$50 \%$

$21 \%$

$0 \%$

$29 \%$

$33 \%$

$17 \%$

$17 \%$

$67 \%$

Total

$100 \%$ $100 \%$ $100 \%$ $100 \%$ $100 \%$ $100 \%$

$27 \%$

$27 \%$

$100 \%$

32

35

41 148 
Table A1. Regression of own perception of rainfall

\begin{tabular}{lrr}
\hline & Coeff. & t-value \\
Average perception of rainfall & & \\
in contiguous communes & 0.739913 & $\mathbf{2 0 . 8 7}$ \\
Intercept & 0.155252 & $\mathbf{6 . 5 7}$ \\
Number of observations & 1383 & \\
R-squared & 0.240 & \\
\hline
\end{tabular}




\begin{tabular}{|c|c|c|}
\hline Composition of focus group & Coefficient & t-value \\
\hline Size of the group (in log) & 0.144 & 1.019 \\
\hline Share communal employees & 0.241 & 0.809 \\
\hline Share social/public employees & -0.440 & -1.290 \\
\hline Share village leaders & -0.827 & -1.623 \\
\hline Share farmers & $0.941^{\star *}$ & 2.493 \\
\hline Gripe proxy from rainfall regression $\left({ }^{*}\right)$ & 0.041 & 0.321 \\
\hline Gripe proxy from crime regression $\left({ }^{* *}\right)$ & $-0.391^{\star \star \star}$ & -8.234 \\
\hline \multicolumn{3}{|l|}{ Climatic and agricultural shocks } \\
\hline Cyclone & $-0.088^{*}$ & -1.755 \\
\hline Flood & 0.040 & 1.126 \\
\hline Broken bridge or cut road & 0.024 & 0.767 \\
\hline Dought & $0.095^{\star \star \star}$ & 2.707 \\
\hline Rice fleas & -0.046 & -1.500 \\
\hline Phytosanitary diseases & 0.001 & 0.040 \\
\hline Frost/hail & -0.031 & -0.676 \\
\hline Locusts & -0.057 & -1.152 \\
\hline Late start of rains & -0.073 & -1.509 \\
\hline \multicolumn{3}{|l|}{ Human diseases } \\
\hline Tuberculosis & $0.049^{*}$ & 1.733 \\
\hline Typhoid & -0.017 & -0.550 \\
\hline Cholera & -0.050 & -0.963 \\
\hline Plague & -0.044 & -0.857 \\
\hline \multicolumn{3}{|l|}{ Livestock diseases } \\
\hline Maladie du charbon bacterien & -0.006 & -0.194 \\
\hline Maladie du charbon symptomatique & 0.055 & 1.605 \\
\hline Pig plague & 0.042 & 1.358 \\
\hline Other livestock epidemic & -0.024 & -0.778 \\
\hline Province dummies & $\mathrm{Y}$ & \\
\hline Intercept & $-0.862^{* *}$ & -2.069 \\
\hline Number of observations & 1352 & \\
\hline
\end{tabular}

Significance levels as follows: .01- ${ }^{* * *} ; .05-^{* *} ; .1-^{*}$;

$\left({ }^{*}\right)$ Residual from Table A1.

$\left({ }^{\star \star}\right)$ Residual from OLS regression with same regressors as Table 3. 
Table A3: Instrumenting regression for increase in insecurity

\begin{tabular}{|c|c|c|}
\hline Share of pop. 10-14 - share of pop. 15-19 (1993) & Coefficient & t-value \\
\hline In commune & $-4.793^{* *}$ & -1.972 \\
\hline In neighboring communes & $-6.808^{*}$ & -1.746 \\
\hline \multicolumn{3}{|l|}{ Composition of focus group } \\
\hline Size of the group (in log) & 0.064 & 1.228 \\
\hline Share communal employees & 0.094 & 0.882 \\
\hline Share social/public employees & -0.133 & -1.101 \\
\hline Share village leaders & $-0.299^{*}$ & -1.707 \\
\hline Share farmers & $0.326^{* *}$ & 2.498 \\
\hline Gripe proxy from rainfall regression $\left(^{*}\right)$ & 0.015 & 0.338 \\
\hline Gripe proxy from crime regression $\left({ }^{* *}\right)$ & $-0.141^{\star * \star}$ & -8.291 \\
\hline \multicolumn{3}{|l|}{ Climatic and agricultural shocks } \\
\hline Cyclone & $-0.033^{*}$ & -1.764 \\
\hline Flood & 0.014 & 1.047 \\
\hline Broken bridge or cut road & 0.008 & 0.748 \\
\hline Dought & $0.037^{* * *}$ & 2.773 \\
\hline Rice fleas & $-0.020^{*}$ & -1.762 \\
\hline Phytosanitary diseases & 0.005 & 0.439 \\
\hline Frost/hail & -0.004 & -0.260 \\
\hline Locusts & -0.022 & -1.265 \\
\hline Late start of rains & $-0.030^{*}$ & -1.662 \\
\hline \multicolumn{3}{|l|}{ Human diseases } \\
\hline Tuberculosis & 0.015 & 1.466 \\
\hline Typhoid & -0.009 & -0.778 \\
\hline Cholera & -0.018 & -0.992 \\
\hline Plague & -0.008 & -0.504 \\
\hline \multicolumn{3}{|l|}{ Livestock diseases } \\
\hline Maladie du charbon bacterien & -0.002 & -0.193 \\
\hline Maladie du charbon symptomatique & 0.017 & 1.375 \\
\hline Pig plague & 0.017 & 1.532 \\
\hline Other livestock epidemic & -0.008 & -0.752 \\
\hline Province dummies & Yes & \\
\hline Intercept & $0.286^{*}$ & 1.814 \\
\hline Number of observations & 1335 & \\
\hline R-squared & 0.1335 & \\
\hline Test that instruments are jointly significant & $\begin{array}{r}F(2,1305) \\
5.98\end{array}$ & $\begin{array}{r}\mathrm{p} \text {-value } \\
0.0026\end{array}$ \\
\hline
\end{tabular}

Significance levels as follows: $.01-^{* * *} ; .05-^{* *} ; .1-^{*}$;

$\left({ }^{*}\right)$ Residual from Table A1.

$\left.{ }^{(*}\right)$ Residual from OLS regression with same regressors as Table 3. 
${ }^{\mathrm{i}}$ We have benefited from comments from Esther Duflo, Michael Kremer, Ted Miguel, and other participants to the McArthur conference held in Naivasha in 2006. We thank the World Bank and USAID for funding this research. We also would like to thank Elaine Ralison, Lalaina Randrianarson, Jean-Claude Randrianarisoa, Christine Moser, Milasoa Cherel-Robson and our team of enumerators for assisting with data collection. The support of the Economic and Social Research Council (UK) is gratefully acknowledged. The work was part of the programme of the ESRC Global Poverty Research Group.

ii Department of Economics, University of Oxford, Manor Road, Oxford OX1 3UQ. Email: marcel.fafchamps@economics.ox.ac.uk. Fax: +44(0)1865-281447. Tel: +44(0)1865-281446. iii Senior Research Fellow, International Food Policy Research Institute, New Delhi Office, CG Block, NASC Complex, PUSA, New Delhi 110012 India. Phone: +91 11-2584-6565/6566/6567. Email: B.Minten@cgiar.org

${ }^{\text {iv }}$ After a disputed presidential election, the country was temporarily divided into two in early 2002, each faction occupying part of the island. After a blockade of the Central Highlands that lasted several months, the stand-off was eventually resolved when the incumbent president fled the country in June 2002. In spite of the severity of the political crisis, the level of political violence was kept surprisingly low, with estimates of crisis-related casualties numbering less than 100 victims.

"The exact number remains unclear due to the existence of conflicting "official" lists. This confusion is the result of changes in the boundaries and composition of some communes in the mid-1990s.

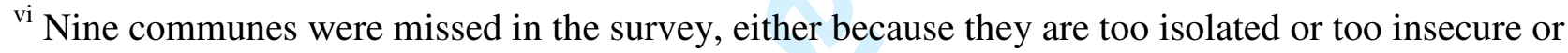
both. The number of missing communes is very small so selection bias is unlikely to be an issue in the estimation.

vii The high incidence of cattle rustling may be related to traditional practices of certain ethnic groups. The Bara, one of the dominant ethnic groups in Southwestern Madagascar, are known cattle thieves because young men are supposed to prove their manhood by stealing cattle. When they have done so, they are ready to get married (Ramiarantsoa, 1995). The Sakalava have similar customs. Cattle rustling is more common in the western part of the island. This largely reflects the fact that this drier part of the island is most suitable for extensive livestock production, which naturally facilitates livestock theft (Smith, Barrett and Box, 2001).

${ }^{\text {viii }}$ It is conceivable that the feeling of insecurity responds more strongly to recent events. To investigate this possibility, we reestimate the model using only crime reported in the year preceding the survey (2001) and only crime reported in 1999. We obtain slightly stronger results (higher $t$ values) using 2001 crime data or the 1999-2001 average than using the 1999 numbers. But the results are otherwise quite similar.

${ }^{\text {ix }}$ We omit malaria and two animal diseases -- distomatosis and Newcastle disease -- because they are endemic in the entire country and have too little variation for their coefficient to be identified. Including them does not change the conclusions regarding insecurity, however.

${ }^{\mathrm{x}}$ The regression by and large satisfies the balancing property. Balancedness is violated at the $5 \%$ level in two cases (out of a total of 24 variables times 7 blocks) involving two different variables in two different blocks, without any evidence of a pattern.

${ }^{\mathrm{xi}}$ It is also conceivable that the presence of young males coming of age during the period covered by our analysis had an worsening effect on crime and insecurity because crime (especially violent 
crime) is often correlated with testosterone levels (Wilson, Daly and Pound, 2002). We would expect this pattern in societies where crime is perpetrated by nearby residents, but it is unlikely to apply to rural Madagascar where cattle rustling by itinerant gangs is the major security concern. ${ }^{x i 1}$ Unfortunately, we do not have longitudinal information on agricultural prices at the commune level and cannot therefore test whether communes that became more insecure experienced a fall in agricultural prices.

${ }^{x i i i}$ For lowland cultivation, $3 \%$ of communes cited insecurity as the first reason for not expanding acreage; another $7 \%$ cited it as second reason. For upland cultivation, insecurity was cited as first and second reason by $8 \%$ and $15 \%$ of communes, respectively.

${ }^{\mathrm{xiv}}$ It is not contended that service provision helps welfare. It is thus not really necessary for us to demonstrate that a link exists in our data as well. The reader may nevertheless like to know that when change in public provision is added to Table 8, results conform with expectations -- adding a school raises school enrollment, adding agricultural input and output markets raises incomes, and adding a health center tends to raise health status and reduce infant mortality. The latter effect, however, is only significant at the 15 to $20 \%$ level.

${ }^{\mathrm{xv}}$ This survey covered a sample of 150 communes and was undertaken in November 2002. 